\title{
KARAKTERISASI DAN PROPORSI ABU TERBANG (FLY ASH) DALAM PEMBUATAN PCC (PORTLAND COMPOSITE CEMENT)
}

\author{
Finda Pratiwi Istomo, Nurlela Nurlela* \\ Program Studi Kimia, Fakultas MIPA, Universitas Nusa Bangsa, \\ Jl. KH. Sholeh Iskandar Km. 4, Tanah Sereal, Bogor 16166, Indonesia \\ *e-mail: nurlela.kimia@gmail.com
}

\begin{abstract}
Characterization and Proportion of Fly Ash in The Making of PCC (Portland Composite Cement)
\end{abstract}

\begin{abstract}
Coal is used as fuel to form clinker, which is the base material for cement. The resulting residue is fly ash that can pollute the air. Fly ash is pozzolanic that reacts with lime and is binding, it can be used as an additional material in cement making as a substitute for trass. Therefore, it is interesting to conduct study on the proportion of fly ash in order to obtain cement quality that meets the requirements of SNI 0302-2014. The research method used was characterization of oxides in fly ash using XRF, optimization of fly ash grinding, mixing cement blanks with fly ash samples, and chemical and physical testing. The composition of fly ash that was added to the cement blank is 0\%, $10 \%, 20 \%, 30 \%$, and 40\%. The results of chemical and physical testing showed that the more fly ash added, it would affect the quality of the cement produced. The free lime test showed that the more fly ash added, the free lime content decresead, while for the insoluble part and the flare loss parameters were increased. Physical testing includes fineness, air content, expansion, and setting time, were increased while the residual test was decreased. Based on the results, to conclude that the addition of 10\%-30\% fly ash fulfilled the requirements of SNI 0302-2014.
\end{abstract}

Keywords: Portland Composite Cement, Fly Ash, Composition, Chemical and Physical Testing

\begin{abstract}
ABSTRAK
Batubara digunakan sebagai bahan bakar untuk membentuk klinker yang merupakan bahan dasar semen. Residu yang dihasilkan yaitu abu terbang/fly ash yang dapat mencemari udara. Fly ash bersifat pozzolan dapat bereaksi dengan kapur dan bersifat mengikat, sehingga dapat digunakan sebagai bahan tambahan dalam pembuatan semen yaitu pengganti material trass. Oleh karena itu, perlu dilakukan penelitian terhadap proporsi fly ash agar mendapat kualitas semen yang memenuhi persyaratan SNI 0302-2014. Metode penelitian yang dilakukan adalah karakterisasi oksida dalam fly ash menggunakan XRF, optimasi penggilingan sampel fly ash, pencampuran blanko semen dengan sampel fly ash, dan pengujian kimia dan fisika. Pengujian kimia meliputi uji kapur bebas, uji bagian tak larut, uji hilang pijar dan uji XRF. Sedangkan untuk pengujian fisika meliputi uji kehalusan, uji residu dengan ayakan $45 \mu \mathrm{m}$, uji kandungan air, uji pemuaian, uji nilai konsistensi, uji setting time, dan uji kuat tekan. Komposisi fly ash yang ditambahkan pada blanko semen adalah 0\%, 10\%, 20\%, 30\%, dan 40\%. Hasil uji kimia dan fisika didapatkan semakin banyak penambahan fly ash maka akan mempengaruhi kualitas dari semen yang dihasilkan. Hasil uji kimia kapur bebas mengalami penurunan, sedangkan untuk uji bagian tak larut dan uji hilang pijar mengalami kenaikan. Pengujian fisika meliputi uji kehalusan, uji kandungan udara, uji pemuaian, uji setting time, mengalami kenaikan sedangkan uji residu mengalami penurunan. Berdasarkan hasil penelitian dapat disimpulkan bahwa penambahan fly ash 10\%-30\% memenuhi persyaratan SNI 0302-2014.
\end{abstract}

Kata kunci: Portland Composite Cement, Fly ash, Karakterisasi, Komposisi, Uji Kimia dan Fisika

\section{PENDAHULUAN}

Infrastruktur dan properti di Indonesia berkembang pesat. Oleh karena itu, kebutuhan akan material penunjang juga semakin meningkat. Salah satu bahan komponen dalam pembangunan infrastruktur dan properti adalah semen. Seiring dengan kebutuhan semen yang semakin meningkat, industri semen juga mengalami perkembangan yang sangat pesat. Hal ini mengakibatkan persaingan dalam pemasaran semen akan semakin ketat. Untuk itu diperlukan sistem pengendalian mutu yang optimal agar dihasilkan semen yang berkualitas baik dan memenuhi persyaratan yang telah diinginkan. 
Dalam industri pembuatan semen, batubara digunakan sebagai bahan bakar dalam kiln untuk membentuk klinker yang merupakan bahan dasar semen. Batubara adalah salah satu sumber energi yang penting bagi dunia. Batubara banyak memainkan peran selama ribuan tahun, tidak hanya membangkitkan listrik namun juga merupakan bahan bakar utama bagi kegiatan-kegiatan industri seperti industri semen (Rendy et al., 2014). Batubara yang digunakan sebagai bahan bakar diharapkan memiliki nilai kalor yang tinggi untuk mendapatkan efisiensi pembakaran (Lutfy et al., 2013).

Pembakaran batubara ini menghasilkan residu yang dikenal dengan $f l y$ ash atau abu terbang serta bottom ash atau abu dasar. Abu terbang apabila dibuang pada udara terbuka akan mengakibatkan pencemaran karena mengandung beberapa elemen seperti arsen, vanadium, antimon, boron, kromium sehingga dapat disimpulkan bahwa hasil dari penggunaan batubara akan menghasilkan limbah (Sumajouw et al., 2013).

Bahan pozzolan di kelompokan menjadi dua jenis, yaitu bahan pozolanik alami dan bahan pozzolanik buatan. Bahan yang dikelompokan menjadi pozzolanik alami adalah trass, sedangkan bahan yang dikelompokan menjadi pozzolanik buatan adalah Blast Furnace Slag, Fly ash (ASTM 593-82). Fly ash bersifat pozzolan yang berarti abu tersebut dapat bereaksi dengan kapur dan bersifat mengikat (Maryoto, 2008) sehingga dapat digunakan sebagai bahan tambahan dalam pembuatan semen. Untuk mengurangi limbah/residu dari industri pembuatan semen, maka bisa memanfaatkan sisa dari pembakaran batu bara yang berupa fly ash untuk dicampurkan pada klinker sebagai pengganti material yang selama ini digunakan yaitu trass. Untuk memperoleh semen dengan penambahan fly ash yang memiliki kualitas baik tetapi dengan harga yang lebih ekonomis, perlu dilakukan penelitian optimasi dan karakterisasi fly ash yang akan ditambahkan pada proses pembuatan semen. Penelitian ini bertujuan untuk mengkarakterisasi komposisi oksida dalam fly ash menggunakan X-ray Fluorescence (XRF), mendapatkan kondisi waktu terbaik dalam proses preparasi penggilingan fly ash, menentukan proporsi fly ash dan klinker dalam pembuatan semen, dengan melakukan uji kimia dan fisika untuk menghasilkan produk Portland Composite Cement dengan kualitas yang memenuhi persyaratan SNI 0302-2014.

\section{BAHAN DAN METODE}

\section{Bahan dan Alat}

Bahan-bahan yang digunakan adalah $\mathrm{HCl}$ pekat, $\mathrm{HCl} 1 / 14 \mathrm{~N}$, indikator Fenolftalein (PP) $1 \%$, etilen glikol $\left(\mathrm{C}_{2} \mathrm{H}_{6} \mathrm{O}_{2}\right)$, kertas saring Whatman No. 40 dan 41, larutan $\mathrm{NH}_{4} \mathrm{NO}_{3} 20 \%$, larutan natrium hidroksida $10 \%$, metil merah, pil CGA (Cement Grinding Aid), akuades, air kapur jernih, pasir silika standar (C-109 dan C190), cairan manometer (dibutil ftalat), fly ash, klinker. Alat-alat yang digunakan adalah Furnace Thermolyne 48000, desikator, cawan krusibel, neraca analitik, gelas ukur $50 \mathrm{~mL}$, pengaduk magnetik, hot plate, piala gelas $250 \mathrm{~mL}$, vessel disk, grinding machine Herzog tipe HSM $100 \mathrm{H}$, ring, press machine Herzog tipe HTP 40, XRF ARL 8480S, cassette, cetakan kubus (mold), mesin pengaduk Hobart, pengaduk, mangkuk aduk, meja alir dan cetakan alir, penumbuk, pisau aduk, pisau segi tiga, mesin kuat tekan Toni Technik, sel permeabilitas, piringan, torak, kertas saring, manometer, alat pencatat waktu, corong kecil, kuas kecil berbulu halus, sieve frame No. 325, spray nozzle, pengukur tekanan, peralatan vicat, pisau tumpul, ring ebonit, oven Memmert UNE 700.

\section{Metode}

\section{Pembuatan Semen}

Penelitian ini menggunakan blanko semen dengan abu terbang. Sampel abu terbang sebelumnya di keringkan dalam oven $(105 \pm 5) \quad{ }^{\circ} \mathrm{C}$ selama 24 jam. Sebelum dilakukan pencampuran, abu terbang di analisis komposisi kimianya dengan XRF. 
Tabel 1. Perbandingan komposisi semen dan abu terbang

\begin{tabular}{clcccc}
\hline No & Kode & Persentase Fly Ash (\%) & Blanko (gram) & Abu Terbang (gram) & Pasir (gram) \\
\hline 1 & PCC-1 & 0 & 740 & 0 & 2035 \\
2 & PCC-2 & 10 & 666 & 74 & 2035 \\
3 & PCC-3 & 20 & 592 & 148 & 2035 \\
4 & PCC-4 & 30 & 518 & 222 & 2035 \\
5 & PCC-5 & 40 & 444 & 296 & 2035 \\
\hline
\end{tabular}

Tahap selanjutnya dilakukan pencampuran semen dengan melakukan penimbangan contoh berdasarkan komposisi yang telah ditetapkan (Tabel 1). Semua contoh dihaluskan dengan menggilingnya sampai mencapai kehalusan 3800-4000 $\mathrm{cm}^{2} / \mathrm{gram}$ dengan alat penggiling (grinding mill), setelah itu dihomogenisasi.

\section{Uji Hilang Pijar (ASTM C-114)}

Semen ditimbang dengan teliti sebanyak 1 gram dan dimasukkan ke dalam cawan porselen yang telah diketahui bobot tetapnya. Kemudian dimasukkan cawan porselen tersebut ke dalam tanur yang suhunya $400{ }^{\circ} \mathrm{C}$ selama 30 menit. Lalu, suhu furnace diubah menjadi $(1000 \pm 20)^{\circ} \mathrm{C}$ dan dipijarkan lagi selama 1 jam pada suhu tersebut. Cawan porselen dan sampel yang telah dipijarkan didinginkan dalam desikator selam 30 menit, bobot setelah pemijaran ditimbang.

Rumus kadar Hilang Pijar:

Hilang Pijar $(\%)=\frac{(\mathrm{A}-\mathrm{B})}{\mathrm{C}} \times 100 \%$

Keterangan:

A = bobot krusibel + sampel (gram)

B = bobot krusibel setelah pemijaran (gram)

$\mathrm{C}=$ bobot sampel(gram)

\section{Uji Kapur Bebas (ASTM STP-985)}

Semen ditimbang teliti 1 gram, dimasukkan ke dalam piala gelas $250 \mathrm{~mL}$. Kemudian ditambahkan $25 \mathrm{~mL}$ etilen glikol dengan suhu $85^{\circ} \mathrm{C}$, lalu dipanaskan dan diaduk dengan bantuan pengaduk magnetik. Setelah itu larutan disaring dengan bantuan vakum, lalu ditambahkan \pm 3 tetes indikator PP 1\% hingga warna larutan berwarna merah muda. Larutan ditirasi dengan $\mathrm{HCl}$ $1 / 14 \mathrm{mg} / \mathrm{L}$ sampai warna larutan berubah dari warna merah muda menjadi tak berwarna.
Rumus kadar Kapur Bebas:

Kapur bebas $(\%)=\frac{\mathrm{V}_{\mathrm{p}} \times \mathrm{N}_{\mathrm{HCl}} \times \mathrm{Bst} \mathrm{CaO} \times 100 \%}{\mathrm{w} \times 1000}$

Keterangan :

$V_{\text {penitar }}=$ Volume $\mathrm{HCl}$ y ang dibutuhkan pada titrasi (ml)

Bst $\mathrm{CaO}=$ Bobot ekivalen $\mathrm{CaO}(28)$

$1000=$ Nilai konversi satuan

$N_{H C l}=$ Normalitas $\mathrm{HCl}(\mathrm{mol} / \mathrm{L})$

$w=$ Berat $\quad$ sampel (gram)

\section{Uji bagian tak larut (ASTM C114-15)}

Semen ditimbang dengan teliti sebanyak 1 gram contoh, masukkan ke dalam piala gelas $250 \mathrm{~mL}$, tambahkan 25 $\mathrm{mL}$ akuades dan $5 \mathrm{~mL} \mathrm{HCl}$ pekat. Bila perlu, panaskan larutan dan tekan-tekan contoh dengan ujung batang pengaduk kaca sampai terurai sempurna. Diencerkan larutan sampai dengan $50 \mathrm{~mL}$ dengan air panas dan dipanaskan di atas hot plate sampai mendekati titik didih. Disaring melalui kertas saring berpori medium ke dalam piala gelas $400 \mathrm{~mL}$, cuci piala gelas, kertas saring dan endapan 10 kali dengan akuades panas dan filtrat digunakan untuk penetapan $\mathrm{SO}_{3}$. Dipindahkan kertas saring dan endapan ke dalam piala gelas semula, ditambahkan 100 $\mathrm{mL}$ larutan $\mathrm{NaOH} 10 \%$ panas dan di-digest selama 15 menit pada suhu hampir mendidih.

Selama di-digest sekali-sekali diaduk campuran dan dihancurkan kertas saring dengan batang pengaduk. Asamkan larutan dengan $\mathrm{HCl}$ dan gunakan metil merah sebagai indikator, ditambahkan $\mathrm{HCl}$ berlebih (4-5) tetes. Saring dengan kertas saring berpori medium dan dicuci endapan sekurang-kurangnya 14 kali dengan larutan $\mathrm{NH}_{4} \mathrm{NO}_{3} 20 \%$ panas untuk meyakinkan bahwa kertas saring dan isinya tercuci sempurna. Kertas saring dan isinya dimasukkan ke dalam krusibel yang telah diketahui beratnya lalu abukan dan pijarkan 
pada suhu $\quad(900-1000)^{\circ} \mathrm{C}$ sekurangkurangnya 30 menit. Dinginkan dalam desikator kemudian timbang. Lakukan penetapan blanko dengan menggunakan pereaksi dan cara yang sama. Perhitungkan hasilnya sebagai koreksi dalam perhitungan. Rumus kadar Bagian Tak Larut :

Bagian tak larut $(\%)=\frac{((\mathrm{B}-\mathrm{A})-\text { blanko })}{\mathrm{C}} \times 100 \%(3)$

Keterangan:

$$
\begin{aligned}
A & =\text { bobot krusibel kosong (gram) } \\
B & =\text { bobot krusibel + endapan (gram) } \\
\boldsymbol{C} & =\text { bobot sampel (gram) } \\
\text { Blanko } & =\text { faktor koreksi (gram) }
\end{aligned}
$$

\section{Uji Komposisi Kimia dengan X-RF (ASTM C114-10)}

Semen ditimbang sebanyak 15 gram, dimasukkan ke dalam vessel disk. Lalu sebanyak 2 butir cement grinding aid (CGA) ditambahkan. Vessel disk disimpan pada grinding machine, dioperasikan \pm 2 menit. Contoh semen yang telah digiling dimasukkan ke dalam ring yang sudah siap untuk di press oleh press machine dengan kuat tekanan 10 sampai 12 ton selama 5 detik. Contoh semen yang telah di press selanjutnya siap untuk dianalisis dengan spektrometer pendarfluor sinar-X.

Contoh semen dimasukkan ke dalam cassette dan diletakkan pada tempat contoh spektrometer pendarfluor sinar-X. Alat dikondisikan (drift correction, kurva kalibrasi) untuk operasi sesuai tipe spektrometer pendarfluor sinar X dan jenis contoh yang akan dianalisis. Analisis dilakukan sesuai tipe spektrometer pendarfluor sinar-X secara otomatis akan menganalisis contoh dan data hasil analisis secara otomatis akan terlihat di layar monitor.

\section{Penyiapan Benda Uji}

Sisa-sisa mortar yang menempel pada cetakan dibersihkan. Kain yang sudah diolesi minyak/gemuk dibuat lapisan tipis pada cetakan di bagian dalam dan dasar plat. Cetakan dan pasangannya diklem hingga rapat, lalu ditempelkan pada dasar plat dan diklem sampai rapat, jangan sampai ada kebocoran di bagian sambungan.

\section{Penyiapan Mortar}

Mortar disiapkan dengan perbandingan bobot [semen (1): pasir silika standar $(2,75)$ : air $(0,485)]$ untuk membuat sembilan benda uji dalam satu kali pengerjaan memerlukan $740 \mathrm{~g}$ semen, 2035 g pasir silika standar (C-109), dan $359 \mathrm{~g}$ air. Semen dan air dimasukkan ke dalam mesin pengaduk dengan kecepatan rendah yaitu $140 \pm 5$ rpm selama 30 detik. Pasir perlahan ditambahkan. Kecepatan dinaikkan hingga $285 \pm 10 \mathrm{rpm}$ selama 30 detik, sisa-sisa mortar yang menempel dibersihkan, kemudian dilanjutkan pengadukan hingga 1 menit.

\section{Pencetakan Benda Uji}

Pencetakan dilakukan segera setelah pengadukan. Dituangkan mortar dengan ketinggian $\pm 25 \mathrm{~mm}$ pada cetakan kubus, ditumbuk mortar tersebut. Jika penumbukan lapisan pertama sudah selesai, sisa mortar dituangkan ke dalam cetakan dan ditumbuk kembali, setelah tiap kali penumbukan selesai. Ujung kubus harus sedikit lebih tinggi dari ujung cetakan, lalu mortar di atas cetakan diratakan.

\section{Penyiapan Benda Uji}

Setelah pencetakan benda uji selesai, dengan segera benda uji ditempatkan ke dalam wadah yang lembab selama 24 jam dengan permukaan atasnya kontak dengan udara lembab tetapi harus dihindarkan dari tetesan air. Benda uji dikeluarkan dari cetakan dan diberi identitas, kemudian direndam dalam wadah penyimpanan yang berisi air kapur jenuh. Benda uji dikeluarkan dari perendaman hanya benda uji yang akan dilakukan uji kuat tekan saja, sedangkan yang akan diuji kuat tekan pada umur umur lanjut tetap dibiarkan dalam bak perendaman.

\section{Penentuan Kuat Tekan}

Pengujian segera dilakukan setelah benda uji dikeluarkan dari wadah lembab dengan menggunakan alat kuat tekan, mortar diuji kuat tekannya hingga pecah dengan persyaratan seperti pada Tabel 2. Benda uji yang dikeluarkan dari wadah lembab harus dijaga dalam air pada suhu $23 \pm 1,7^{\circ} \mathrm{C}$ hingga pengujian dilaksanakan. 
Tabel 2. Toleransi Waktu Pengukuran Kuat Tekan

\begin{tabular}{|c|c|}
\hline Umur (hari) & $\begin{array}{c}\text { Toleransi yang } \\
\text { diperbolehkan (jam) }\end{array}$ \\
\hline 3 & $\pm 1,0$ \\
\hline 7 & $\pm 3,0$ \\
\hline 28 & $\pm 12,0$ \\
\hline
\end{tabular}

(Sumber: Vera, et al., 2000)

Setiap benda uji diseka sampai kondisi kering permukaan dan dihilangkan butiran-butiran pasir yang lepas. Beban diberikan pada permukaan benda uji yang pada pencetakannya kontak dengan permukaan yang rata dari cetakan, kemudian benda uji ditempatkan tepat di bawah titik pusat dari landasan blok atas. Laju penekanan sedemikian rupa sehingga beban maksimum akan tercapai, tidak kurang dari 20 detik dan tidak lebih dari 80 detik sejak penekanan dimulai, lalu catat tonase dari penekanan mortar. Rumus Penentuan Kuat Tekan yaitu:

Kuat $\operatorname{Tekan}\left(\mathrm{kg} / \mathrm{cm}^{2}\right)=\mathrm{X} \times$ Faktor $\times 38,75(4)$

Keterangan:

$X=$ Hasil pengukuran dengan alat kuat tekan (ton)

Faktor $=$ Faktor kalibrasi dari alat kuat tekan

$38,75=$ Nilai konversi satuan $\left(\mathrm{kg} / \mathrm{cm}^{2}\right.$ ton $)$

\section{Uji Kehalusan Semen Menggunakan Alat Blaine (ASTM C-204)}

Semen yang akan diuji didiamkan hingga suhunya sama dengan suhu ruangan. Logam berbentuk piringan diletakan di dasar sel dan kertas saring disimpan di atas piringan logam tersebut. Ditekan menggunakan batang memiliki diameter lebih kecil daripada diameter sel.

Semen ditimbang 0,001 g, dengan menggunakan corong dan kuas, semen dimasukkan ke dalam sel, kemudian diketuk bagian luar sel agar lapisan contoh di dalamnya rata. Kertas saring diletakan di atas contoh dan ditekan dengan torak sampai leher torak kontak dengan permukaan sel, ditarik torak sedikit ke atas, diputar $90^{\circ}$ dan tekan kembali, perlahan torak ditarik keluar sel.

Sel permeabititas disambungkan pada tabung manometer dengan sambungan yang kedap udara, dikeluarkan udara yang ada dalam salah satu tabung manometer dengan menggunakan pompa karet hingga cairan manometer mencapai tanda garis ketiga. Suhu pengujian dan waktu (detik) dicatat.

\section{Uji Kehalusan Semen dengan Ayakan 45 $\mu \mathrm{m}$ (ASTM C-430)}

Sebanyak $\pm 10 \mathrm{~g}$ contoh semen ditimbang, lalu dimasukkan ke dalam sieve frame nomor 325 yang bersih dan kering, kemudian dibasahi contoh dengan aliran air yang kecil, setelah itu dipindahkan sieve frame dari bawah pipa semprot (nozzle) dan diatur tekanan air pada pipa semprot sampai (10 $\pm 0,5 \mathrm{psi})$. Dikembalikan sieve frame dengan gerakan melingkar pada permukaan horizontal dengan kecepatan satu gerakan per detik pada semprotan air. Bagian bawah spray nozzle berjarak sekitar $12 \mathrm{~mm}(0,5$ inci) dari bagian atas kerangka ayakan.

Sieve frame segera dipindahkan dari pipa semprot, lalu dicuci dengan air suling kira-kira $50 \mathrm{~mL}$ jangan sampai ada residu yang hilang, dikeringkan sieve frame dan residu dalam oven dengan temperatur $105^{\circ} \mathrm{C}$ selama $1 \mathrm{jam}$, setelah itu didinginkan sieve frame dan sikat residu dari sieve frame dengan menggunakan kuas kecil serta timbang dengan neraca. Kemudian berat residu dicatat. Rumus kadar Kehalusan Semen dengan Ayakan $45 \mu \mathrm{m}$ :

$$
\text { Kehalusan }(\%)=\frac{(\mathrm{B}-\mathrm{A}) \times \text { faktor }}{\mathrm{C}} \times 100 \%
$$

$$
\begin{aligned}
& \text { Keterangan: } \\
& \qquad \begin{aligned}
A & =\text { bobot ay akan kosong (gram) } \\
B & =\text { bobot ay akan }+ \text { residu (gram) } \\
C & =\text { bobot sampel (gram) } \\
\text { faktor } & =\text { faktor koreksi ay akan (gram) }
\end{aligned}
\end{aligned}
$$

\section{Uji Normal Consistency (ASTM C-187) Persiapan Pasta Semen}

Semen ditimbang tepat 650 gram, lalu dicampurkan sejumlah air mengikuti prosedur seperti yang dijelaskan dalam prosedur untuk mencampur pasta.

\section{Contoh Uji Cetak}

Pasta semen dibentuk dengan cepat hingga menjadi bentuk seperti bola dengan mengepalkannya menggunakan tangan. 
Kemudian dilemparkan sebanyak enam kali dari satu tangan ke tangan lain yang berjarak $150 \mathrm{~mm}$ hingga membentuk massa bulat yang dapat dengan mudah disisipkan ke dalam ring vicat dengan manipulasi tambahan minimum. Bola ditekan, menggunakan satu telapak tangan, ke ujung ring $\mathrm{G}$ yang lebih lebar, dipegang dengan tangan lainnya, dimasukkan pasta ke dalam ring hingga selesai. Buang sisa pada ujung lebar dengan sekali gerakan telapak tangan. Ditempatkan ring pada bagian ujung lebarnya pada plat dasar H. Kelebihan pasta di bagian ujung ring dipotong dengan sesekali gerakan sekop berujung tajam yang dipegang dengan sudut ringan terhadap bagian atas ring, dan dihaluskan, jika perlu dengan beberapa sentuhan ringan dari ujung sekop. Selama pelaksanaan pemotongan dan penghalusan, hati-hati jangan sampai menekan pasta.

\section{Penentuan Konsistensi}

Pasta terbatas ditempatkan di dalam ring, diletakkan pada plat, di bawah batang $\mathrm{B}$, ujung plunger $\mathrm{C}$ yang akan bersentuhan dengan permukaan pasta, dan dieratkan/dikuatkan set sekrup E. lalu diatur indikator F kepada tanda nol pada skala atau dilakukan pembacaan awal, dan dilepaskan batang dengan segera. Hal ini tidak boleh lebih dari 30 detik setelah pencampuran selesai. Peralatan harus bebas dari semua getaran selama uji. Pasta akan ada pada konsistensi normal ketika batang berada pada titik $10 \pm 1 \mathrm{~mm}$ di bawah permukaan asli dalam 30 detik setelah dilepaskan. Dibuat pasta dengan persentase air yang berbeda-beda hingga konsistensi yang diperoleh normal. Setiap pasta percobaan dibuat dengan semen baru/segar.

\section{Uji Setting Time (ASTM C-430) Persiapan Pasta Semen}

Benda uji yang digunakan merupakan kelanjutan dari benda uji yang digunakan untuk penetapan Normal Consistency dan telah memenuhi spesifikasi uji tersebut. Segera dibentuk pasta semen menjadi bolabola dengan tangan. Tekan bola yang terletak disalah satu telapak tangan, dimasukkan ke ujung yang lebih besar dari ring ebonit, yang dipegang dengan tangan yang lain, dilanjutkan pengisian pasta ke dalam ring. Kelebihan pasta dibuang pada ujung yang lebih besar dari ring dengan sekali gerakan telapak tangan. Jika perlu, dihaluskan benda uji pada bagian atas dengan ujung pisau pengaduk. Pasta jangan sampai ditekan.

\section{Pengujian Setting time}

Benda uji didiamkan dalam wadah lembab selama 30 menit, penetrasi dilakukan menggunakan jarum diameter 1 $\mathrm{mm}$ dengan durasi setiap 15 menit. Jarum D diturunkan hingga menempel di permukaan pasta. Sekrup E dikencangkan dan indikator F diatur skalanya di skala nol. Sekrup E dilonggarkan hingga jarum turun selama 30 detik, skala dicatat. Dengan melakukan interpolasi, ditentukan waktu pengikatan awal yaitu yang menunjukkan penetrasi 25 $\mathrm{mm}$. Saat jarum tidak nampak terbenam pada pasta, maka itulah waktu pengikatan akhir. Dilakukan verifikasi pengikatan akhir dengan mengulang penetrasi dalam selang waktu 90 detik. Peralatan tidak boleh ada getaran selama penetrasi. Jarum dijaga agar tetap lurus dan bersih.

\section{Pemuaian Autoclaf}

Pasta segera diletakkan pada cetakan, lalu simpan di wadah lembab minimal 20 jam. Benda uji dikeluarkan saat 24 jam \pm 30 menit setelah pencetakan, segera diukur panjangnya dan dimasukkan ke dalam autoclaf pada suhu 20-28 ${ }^{\circ} \mathrm{C}$. Katup pelepasan dibuka sampai mulai tampak uap air. Lalu katup ditutup dan suhu autoclave dinaikkan secara bertahap hingga tekanan uap $2 \mathrm{MPa}$ selama \pm 75 menit dari mulai pemanasan. Diusahakan tekanan konstan.

Setelah 3 jam, autoclave didinginkan perlahan. Setelah 1,5 jam, sisa tekanan dilepaskan pelan-pelan. Hitung perubahan panjang benda uji (dalam satuan persen dengan ketelitian 0,01) sebelum dan sesudah pemuaian autoclave.

\section{Air Content (Kandungan Udara) ASTM C 185-02}

Ditimbang tepat komposisi Semen PCC sebanyak 350 gram dengan pasir standar gradasi 20-30\% sebanyak 1400 gram. Ditambah air hingga menjadi mortar. 
Diletakkan adonan mortar pada meja alir di posisi tengah. Diisi cetakan hingga mencapai tinggi $25 \mathrm{~mm}$. Adukan dipadatkan dengan menumbuknya menggunakan alat penumbuk hingga cetakan dipastikan rata. Diisi kembali cetakan hingga penuh dan dipadatkan. Bagian atas diratakan dengan pisau perata. Dibersihkan dan dikeringkan permukaan meja alir di bagian luar cetakan. Cetakan diangkat dari adukan, 1 menit setelah pengerjaan selesai, meja alir diketuk 10 kali dari ketinggian $12,7 \mathrm{~mm}$. Rata-rata penyebaran (dalam satuan persen) diukur menggunakan jangka sorong sebanyak 4 kali dengan sudut yang berbeda.

Jika telah didapat penyebaran yang dimaksud, ditimbang sisa adukan $400 \mathrm{~mL}$. Dimasukkan adukan dengan sendok ke dalam alat ukur dalam 3 lapisan. Masingmasing lapisan dipadatkan dengan cara ditusuk-tusuk menggunakan pisau perata sebanyak 20 kali sepanjang sisi dalam cetakan. Pada penusukan lapisan pertama, tusukan jangan mengenai dasar cetakan. Pada penusukan kedua dan terakhir cukup menembus lapisan masing-masing adukan. Untuk menghilangkan udara yang tertahan dalam adukan, diketuk bagian samping alat ukur perlahan-lahan dengan tongkat penumbuk pada 5 titik yang berbeda sekeliling alat ukur, masing-masing adukan. Untuk menghilangkan udara yang tertahan dalam adukan, diketuk bagian samping alat ukur perlahan-lahan dengan tongkat penumbuk pada 5 titik yang berbeda sekeliling alat ukur, masing-masing $1 \mathrm{kali}$ ketukan. Diratakan permukaan adukan dalam alat ukur dengan pisau perata pada 2 arah yang tegak lurus. Jika pada waktu perataan ada butiran pasir yang keluar dari adukan dan menyebabkan goresan, maka peralatan harus diulangi kembali. Seluruh pekerjaan ini harus diselesaikan dalam waktu 1,5 menit. Dibersihkan adukan dan air yang keluar dari alat ukur. Ditimbang alat ukur dan isinya kemudian dihitung berat adukan dalam gram. Perhitungan kandungan udara dalam mortar:

Kandungan udara $=100-\mathrm{W}[(182,7+\mathrm{P}) /(2000+4 \mathrm{P})](6)$

Keterangan :

$\mathrm{W} \quad=$ Bobot adukan sebanyak $400 \mathrm{~mL}$ (gram)

$\mathrm{P} \quad=$ Persentase air dalam adukan terhadap

bobot semen.

\section{HASIL DAN PEMBAHASAN}

Pada penelitian ini dilakukan pengujian kimia dan fisika terhadap beberapa sampel uji dengan komposisi yang telah ditetapkan sesuai dengan standar SNI 0302-2014 tentang Semen Portland Pozolan. Sebelum dilakukan pencampuran komposisi, sampel fly ash di uji dengan X-Ray Fluorescence (XRF) untuk mengetahui kandungan oksida dalam masing-masing sampel fly ash. Hasil uji XRF bahan baku material fly ash dapat dilihat pada Tabel 3. Untuk pengujian selanjutnya fly ash yang digunakan adalah fly ash Cikarang, karena secara fisik, fly ash cikarang paling mirip dengan semen komersil.

Pada awal penelitian dilakukan optimasi waktu penghalusan limbah fly ash terlebih dahulu dengan tujuan menyeragamkan karakteristik fly ash agar serupa dengan material blanko semen. Dilakukan variasi terhadap waktu penghalusan fly ash. Dari data pada Tabel 4 digunakan waktu penghalusan selama 15 detik dengan dihasilkan parameter uji blaine sebesar $878 \mathrm{~cm}^{2} / \mathrm{g}$ yang berarti dalam 1 gram sampel fly ash mempunyai luas permukaan sebesar $878 \mathrm{~cm}^{2} / \mathrm{g}$ sehingga semakin luas permukaan fly ash maka semakin halus. Residu fly ash yang diperoleh sebesar 26,2 \%. Fly ash yang dihaluskan dalam waktu yang lama, maka akan semakin banyak yang lolos ayakan 45 mikron sehingga semakin sedikit residu yang tertahan.

Tabel 3. Hasil Uji XRF Bahan Baku Material Fly Ash

\begin{tabular}{llllllll}
\multicolumn{1}{c}{ Material } & $\mathrm{LOI}(\%)$ & $\mathrm{SiO}_{2}(\%)$ & $\mathrm{Al}_{2} \mathrm{O}_{3}(\%)$ & $\mathrm{Fe}_{2} \mathrm{O}_{3}(\%)$ & $\mathrm{CaO} \%)$ & $\mathrm{MgO}(\%)$ & $\mathrm{SO}_{3}(\%)$ \\
\hline Fly ash fajar & 8,71 & 44,85 & 20,70 & 21,26 & 15,13 & 12,42 & 2,14 \\
Fly ash cikarang & 3,75 & 38,70 & 3,40 & 23,04 & 19,62 & 7,45 & 0,01 \\
Fly ash indotoray & 1,67 & 41,54 & 3,54 & 16,44 & 12,00 & 17,66 & 0,01 \\
\hline
\end{tabular}


Tabel 4. Optimasi Waktu Penghalusan/Grinding Fly Ash

\begin{tabular}{ccccccl}
\hline \multirow{2}{*}{$\begin{array}{c}\text { No } \\
\text { Sampel }\end{array}$} & $\begin{array}{c}\text { Waktu } \\
\text { Grinding } \\
(\mathrm{s})\end{array}$ & $\begin{array}{c}\text { Blaine } \\
\left(\mathrm{cm}^{2} / \mathrm{g}\right)\end{array}$ & Standar & \multicolumn{2}{c}{ Parameter Uji } & \\
& 0 & & Residu $(\%)$ & $\begin{array}{c}\text { Blaine } \\
\left(\mathrm{cm}^{2} / \mathrm{g}\right)\end{array}$ & $\begin{array}{c}\text { Residu } \\
(\%)\end{array}$ & Keterangan \\
\hline 1 & 0 & & 497 & 28,6 & Sedikit Kasar \\
2 & 15 & Min 300 & Maks 34 \% & 878 & 26,2 & Halus \\
3 & 60 & & & 1014 & 23,4 & Halus \\
4 & 120 & & & 1065 & 21,9 & Halus \\
\hline
\end{tabular}

Dilihat dari hasil penelitian bahwa nilai blaine berbanding terbalik dengan nilai residu. Dalam penelitian ini digunakan penghalusan dengan lama waktu grinding pada 15 detik, diambil yang paling optimum dan efisien karena sebenarnya tanpa di haluskan saja karakteristik fly ash telah masuk persyaratan. Namun, untuk menyeragamkan ukuran di haluskan selama 15 detik agar terhomogenisasi dengan baik dan cepat.

\section{Hasil Uji Kimia}

Setelah sampel fly ash di haluskan kemudian dilakukan pencampuran komposisi sampel untuk di analisis pengujian kimia. Pengujian kimia terdiri dari uji kimia kapur bebas (free lime), uji bagian tak larut (insoluble residu), uji hilang pijar (LOI), dan uji dengan XRF (X-Ray Fluorescence). Hasil pengujian kimia dapar dilihat pada Tabel 5.

\section{Pengaruh Komposisi PCC Terhadap Uji Kimia Kapur Bebas (Free Lime)}

Kapur bebas yang terdapat dalam terak atau semen adalah $\mathrm{CaO}$ yang tidak berikatan dengan oksida-oksida seperti $\mathrm{SiO}_{2}$,
$\mathrm{Al}_{2} \mathrm{O}_{3}$ dan $\mathrm{Fe}_{2} \mathrm{O}_{3}$. Adanya kapur bebas disebabkan oleh 2 hal yaitu:

a. Jumlah kapur yang digunakan berlebihan dengan kebutuhan untuk bereaksi dengan $\mathrm{SiO}_{2}$, $\mathrm{Al}_{2} \mathrm{O}_{3}$, dan $\mathrm{Fe}_{2} \mathrm{O}_{3}$.

b. Reaksi yang berlangsung dalam tanur putar kurang sempurna. (Vera, et al., 2000)

Gambar 1 menunjukan bahwa kadar kapur bebas terendah terdapat pada PCC-4 (40\% fly ash) sebesar 0,28\% dan kadar kapur bebas tertinggi terdapat pada PCC-1 (10\% fly ash) sebesar 0,67\%. Semakin banyak penggunaan fly ash menandakan semakin sedikit penggunaan klinker yang artinya jumlah $\mathrm{CaO}$ bebas yang terbentuk saat pembakaran di reaktor semakin sedikit. Gambar 4 menunjukan bahwa semua kode semen memasuki persyaratan SNI 03022014 yaitu 0,20-0,80 \%. Kadar kapur bebas dalam semen harus dibatasi karena dapat menimbulkan keretakan semen (ekspansi) dan dapat menyebabkan kualitas semen menurun. Kadar kapur bebas ini berbanding terbalik dengan kadar hilang pijar. Semakin tinggi kadar kapur bebas maka kadar hilang pijarnya semakin kecil, begitupun sebaliknya.

Tabel 5. Hasil Pengujian Kimia

\begin{tabular}{|c|c|c|c|}
\hline \multirow[b]{2}{*}{ Kode } & \multicolumn{3}{|c|}{ Pengujian Kimia } \\
\hline & Free Lime (\%) & $\begin{array}{c}\text { Insoluble } \\
\text { Residu }(\%)\end{array}$ & LOI (\%) \\
\hline STD & & & Maks. 5 \\
\hline Blanko Semen & 0,98 & 3,26 & 2,89 \\
\hline PCC-1 (10\% fly Ash) & 0,67 & 5,80 & 3,18 \\
\hline PCC-2 (20\% fly ash) & 0,52 & 9,43 & 3,84 \\
\hline PCC-3 (30\% fly ash) & 0,39 & 13,15 & 4,22 \\
\hline PCC-4 (40\% fly ash) & 0,28 & 18,58 & 4,88 \\
\hline
\end{tabular}




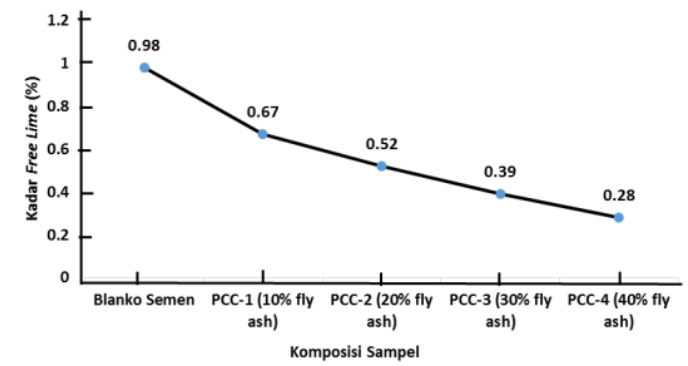

Gambar 1. Pengaruh Komposisi Penambahan Fly Ash Pada Semen terhadap Kadar Free Lime

Pada waktu semen digunakan, selain reaksi hidrasi senyawa-senyawa mineral potensial juga terjadi hidrasi $\mathrm{CaO}$ bebas. Kapur bebas sangat reaktif dengan air, sehingga selama proses penggilingan ataupun penyimpanan, kapur bebas akan mengikat air dari udara. Meskipun demikian, kapur bebas akan bereaksi dengan cepat pada saat air ditambahkan ke dalam dan volume akhir reaksi lebih besar bila dibandingkan sebelum reaksi.

$$
\mathrm{CaO}+\mathrm{H}_{2} \mathrm{O} \longrightarrow \mathrm{Ca}(\mathrm{OH})_{2}
$$

Reaksi hidrasi berlangsung lambat, baru selesai pada waktu pengikatan akhir semen sudah terlampaui, padahal $\mathrm{Ca}(\mathrm{OH})_{2}$ yang terbentuk mempunyai volume lebih besar dari $\mathrm{CaO}$. Pertambahan volume ini (ekspansi) terjadi pada saat semen sudah tidak plastis lagi. Akibatnya timbul keretakan yang dapat menurunkan kualitas semen dikarenakan adanya kapur bebas yang banyak sehingga mengakibatkan pengembangan atau pemuaian semen (Lea \& Desch, 1976).

\section{Pengaruh Komposisi PCC Terhadap Uji Bagian Tak Larut (Insoluble Residue)}

Besarnya kadar bagian tak larut atau IR (Insoluble Residue) ini bergantung banyaknya penambahan fly ash di dalam material penyusun semen. Residu dari fly ash yang tidak larut oleh asam mendominasi dalam komposisi penyusunan semen sehingga semakin banyak penggunaan fly ash maka semakin tinggi nilai Insoluble Residue (IR).

Gambar 2 menunjukkan bahwa kadar IR terendah terdapat pada PCC-1 (10\% fly ash) sebesar 3,26\% dan kadar IR tertinggi terdapat pada PCC-4 (40 \% fly ash) sebesar $18,58 \%$. Untuk semen PCC tidak terdapat batasan karena dalam penggunaan bahan pengisi masih banyak digunakan dengan komposisi yang di sesuaikan. Batas kadar IR tidak ditentukan oleh SNI 0302-2014 tetapi kadar IR ini harus dibatasi karena bertujuan untuk mencegah tercampurnya bahan semen dengan bahan pengotor yang tidak dapat dibatasi oleh persyaratan fisika. Kenaikan kadar bagian yang tak larut sebanding dengan kenaikan komposisi penambahan fly ash di dalam material penyusun semen. Hal ini dikarenakan jumlah $\mathrm{SiO}_{2}$ adalah komponen terbesar sebagai penyusun fly ash. Semakin banyak penambahan fly ash maka semakin besar pula kadar IR, begitupun sebaliknya (Lamond \& Pielert, 2006).

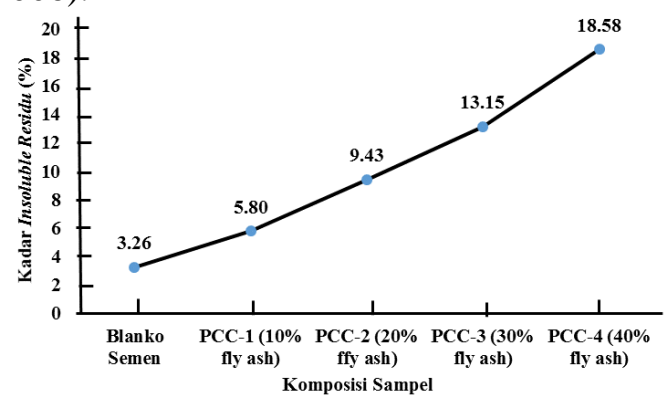

Gambar 2. Pengaruh Komposisi Penambahan Fly Ash Pada Semen terhadap Bagian Tak Larut

\section{Pengaruh Komposisi PCC Terhadap Uji Kimia Hilang Pijar (LOI)}

Hasil penetapan kadar hilang pijar semen menunjukkan kadar hilang pijar terendah terdapat pada PCC-1 (10\% fly ash) sebesar 2,89\% dan kadar hilang pijar tertinggi terdapat pada PCC-4 (40\% fly ash) sebesar 4,88\% dapat dilihat pada Gambar 3 . Semakin banyak penggunaan fly ash dalam pembuatan semen maka nilai hilang pijar semakin tinggi. Batas maksimum kadar hilang pijar yang ditentukan oleh SNI 03022014 adalah maksimum 5,00\%, semua kode semen tersebut memenuhi syarat spesifikasi. Hilang pijar harus dibatasi karena dapat menimbulkan kerusakan dengan tingginya kadar hilang pijar dan dapat menyebabkan kualitas semen menurun karena tingginya $\mathrm{CO}_{2}$ dari batu kapur dan fly ash . 


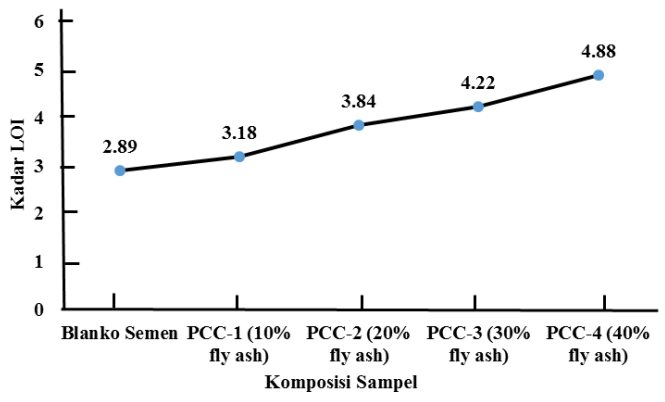

Gambar 3. Pengaruh Komposisi Penambahan Fly Ash Pada Semen terhadap Hilang Pijar

Hilang pijar pada semen disebabkan oleh penguapan air kristal yang berasal dari gipsum dan terjadi pelepasan $\mathrm{CO}_{2}$ yang berasal dari batu kapur dan $\mathrm{SO}_{2}$ yang berasal dari fly ash. Kristal mineral-mineral tersebut pada umumnya dapat mengalami perubahan dalam waktu beberapa tahun, dimana perubahan tersebut dapat menimbulkan kerusakan pada semen. Besarnya hilang pijar tergantung pada banyaknya air kristal gipsum dan pelepasan $\mathrm{CO}_{2}$ yang berasal dari batu kapur dan $\mathrm{SO}_{2}$ yang berasal fly ash.

Penambahan fly ash di dalam semen memberikan kontribusi terhadap kenaikan kadar hilang pijar pada semen karena akan melepaskan $\mathrm{CO}_{2}$ dan $\mathrm{SO}_{2}$, oleh karena itu kadar hilang pijar yang semakin tinggi menunjukkan adanya komponen lain yang terurai menjadi $\mathrm{CO}_{2}$ atau $\mathrm{H}_{2} \mathrm{O}$ pada saat dilakukannya pemijaran. (Vera, et al., 2000).

\section{Pengaruh Komposisi PCC Terhadap Komposisi Oksida}

Komposisi oksida di dalam semen dianalisis menggunakan X-Ray Fluorescence (XRF). Penambahan fly ash pada PCC memberi pengaruh perubahan komposisi oksida PCC seperti $\mathrm{SiO}_{2}, \mathrm{Al}_{2} \mathrm{O}_{3}, \mathrm{Fe}_{2} \mathrm{O}_{3}$, $\mathrm{CaO}, \mathrm{MgO}$ dan $\mathrm{SO}_{3}$. Tabel 6 menunjukkan pengaruh komposisi PCC terhadap uji komposisi kimia dengan XRF.

a. Hasil komposisi $\mathrm{SiO}_{2}$ dalam Semen PCC

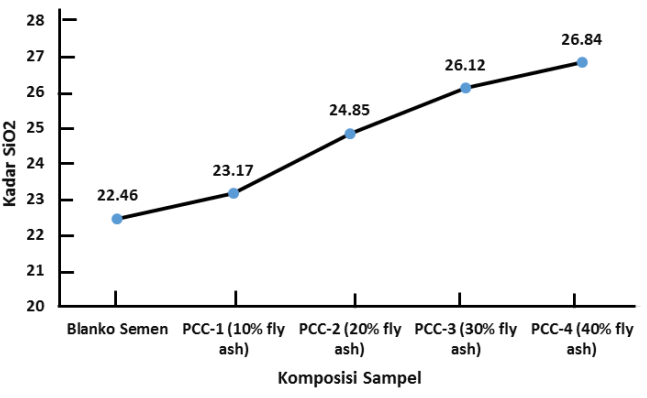

Gambar 4. Hasil komposisi $\mathrm{SiO}_{2}$ dalam Semen PCC

Gambar 4 menunjukkan bahwa kadar $\mathrm{SiO}_{2}$ terendah terdapat pada PCC-1 (10\% fly ash) sebesar 23,17\% dan kadar $\mathrm{SiO}_{2}$ tertinggi terdapat pada PCC-4 (10\% fly ash) sebesar $26,84 \%$. SNI 0302-2014 tidak mencantumkan batas maksimum kadar $\mathrm{SiO}_{2}$ dalam semen. Semakin banyak penambahan fly ash di dalam semen maka semakin tinggi kadar $\mathrm{SiO}_{2}$. Hal ini dikarenakan $\mathrm{SiO}_{2}$ adalah senyawa kedua terbesar setelah $\mathrm{CaO}$ yang terkandung dalam semen. Didalam semen $\mathrm{SiO}_{2}$ selalu berikatan dengan oksida kalsium, sebagai $\mathrm{C}_{3} \mathrm{~S}$ dan sebagai $\mathrm{C}_{2} \mathrm{~S}$.

\section{b. Hasil komposisi $\mathrm{Al}_{2} \mathrm{O}_{3}$ dalam Semen PCC}

Gambar 5 menunjukkan bahwa kadar $\mathrm{Al}_{2} \mathrm{O}_{3}$ terendah terdapat pada PCC-1 (10\% fly ash) sebesar $7,17 \%$ dan kadar $\mathrm{Al}_{2} \mathrm{O}_{3}$ tertinggi terdapat pada PCC-4 (40\% fly ash) sebesar 9,05\%. SNI 0302-2014 tidak mencantumkan batas maksimum kadar $\mathrm{Al}_{2} \mathrm{O}_{3}$ dalam semen. Semakin banyak penambahan fly ash di dalam semen maka semakin tinggi kadar $\mathrm{Al}_{2} \mathrm{O}_{3}$.

Tabel 6. Hasil Analisis Komposisi Kimia dengan XRF

\begin{tabular}{llccccc}
\hline \multirow{2}{*}{ Kode Semen } & \multicolumn{7}{c}{ Data X-RAY } \\
\cline { 2 - 7 } & $\mathrm{SiO}_{2}(\%)$ & $\begin{array}{c}\mathrm{Al}_{2} \mathrm{O}_{3} \\
(\%)\end{array}$ & $\begin{array}{c}\mathrm{F}_{\mathrm{e} 2} \mathrm{O}_{3} \\
(\%)\end{array}$ & $\begin{array}{c}\mathrm{CaO} \\
(\%)\end{array}$ & $\begin{array}{c}\mathrm{MgO} \\
(\%)\end{array}$ & $\begin{array}{c}\mathrm{S}_{3} \\
(\%)\end{array}$ \\
\hline STD PCC & & & & & Maks 6 & Maks 4 \\
BLANKO & 22,46 & 6,39 & 3,79 & 66,23 & 3,06 & 1,93 \\
PCC-1 (10\% fly ash $)$ & 23,17 & 7,17 & 5,61 & 59,52 & 2,39 & 2,22 \\
PCC-2 (20\% fly ash) & 24,85 & 7,74 & 7,88 & 54,67 & 2,71 & 2,57 \\
PCC-3 (30\% fly ash) & 26,12 & 8,36 & 9,75 & 48,51 & 3,14 & 2,68 \\
PCC-4 (40\% fly ash) & 26,84 & 9,05 & 11,89 & 44,90 & 3,45 & 2,94 \\
\hline
\end{tabular}




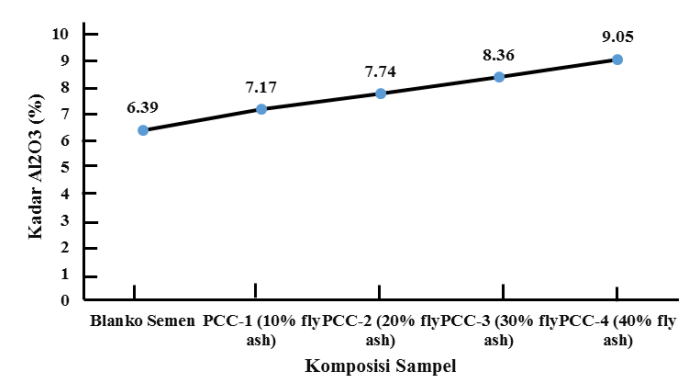

Gambar 5. Komposisi $\mathrm{Al}_{2} \mathrm{O}_{3}$ dalam Semen PCC

\section{c. Hasil komposisi $\mathrm{Fe} 2 \mathrm{O} 3$ dalam Semen PCC}

Gambar 6 menunjukkan bahwa kadar $\mathrm{Fe}_{2} \mathrm{O}_{3}$ terendah terdapat pada PCC1 (10\% fly ash) sebesar 5,61\% dan kadar $\mathrm{Fe}_{2} \mathrm{O}_{3}$ tertinggi terdapat pada PCC-4 (40\% fly ash) sebesar $11,89 \%$. SNI 0302-2014 tidak mencantumkan batas maksimum kadar $\mathrm{Fe}_{2} \mathrm{O}_{3}$ dalam semen. Semakin banyak penambahan fly ash di dalam semen maka semakin tinggi kadar $\mathrm{Fe}_{2} \mathrm{O}_{3}$. Warna pada semen dipengaruhi oleh senyawa kalsium alumina ferrit $\left(\mathrm{C}_{4} \mathrm{AF}\right)$ yang terbentuk dari $\mathrm{Al}_{2} \mathrm{O}_{3}, \mathrm{Fe}_{2} \mathrm{O}_{3}$ dan $\mathrm{CaO}$.

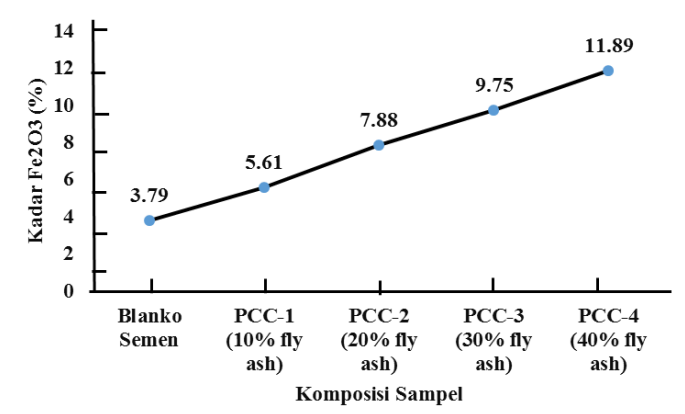

Gambar 6. Komposisi $\mathrm{Fe}_{2} \mathrm{O}_{3}$ dalam Semen PCC

\section{d. Hasil komposisi CaO dalam Semen PCC \\ Gambar 7 menunjukkan bahwa}

kadar $\mathrm{CaO}$ terendah terdapat pada PCC-4 (40\% fly ash) sebesar 44,90\% dan kadar $\mathrm{CaO}$ tertinggi terdapat pada PCC-1 (10\% fly ash) sebesar 59,52 \%. SNI 0302-2014 tidak mencantumkan batas maksimum kadar $\mathrm{CaO}$ dalam semen. Semakin banyak penambahan fly ash maka kadar $\mathrm{CaO}$ yang diperoleh semakin rendah dan juga karena substitusi pemakaian klinker yang semakin berkurang.
Hal ini disebabkan kandungan $\mathrm{CaO}$ pada fly ash tergolong rendah dibandingkan dengan batu kapur dan penambahan batu kapur pada PCC ini tidak dilakukan variasi sehingga menghasilkan kadar $\mathrm{CaO}$ pun dalam $\mathrm{PCC}$ semakin rendah. $\mathrm{CaO}$ juga merupakan senyawa yang bereaksi dengan senyawa silika, alumina dan besi yang membentuk senyawa penyusun utama semen yaitu $\mathrm{C}_{2} \mathrm{~S}$ dan $\mathrm{C}_{3} \mathrm{~S}$.

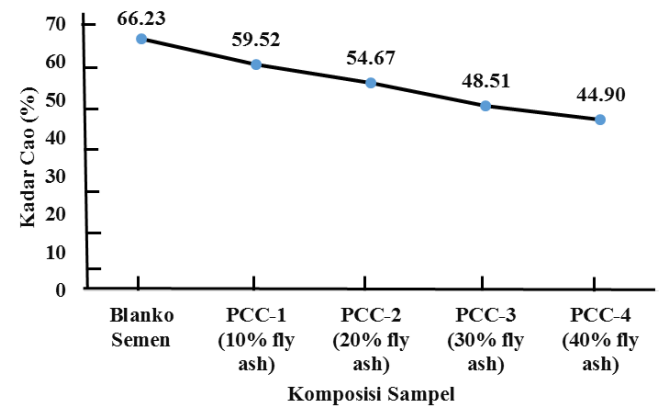

Gambar 7. Komposisi $\mathrm{CaO}$ dalam Semen PCC

\section{e. Hasil komposisi $\mathrm{MgO}$ dalam Semen PCC}

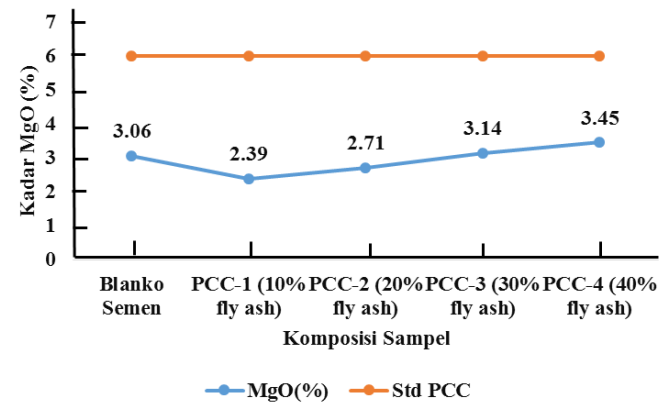

Gambar 8. Komposisi MgO dalam Semen PCC

Gambar 8 menunjukkan bahwa kadar $\mathrm{MgO}$ terendah terdapat pada PCC-1 (10\% fly ash) sebesar 2,39\% dan kadar $\mathrm{MgO}$ tertinggi terdapat pada PCC-4 (40\% fly ash) sebesar $3,45 \%$. Pada SNI 0302-2014 batas maksimum kadar $\mathrm{MgO}$ dalam semen adalah $6,00 \%$. Kadar $\mathrm{MgO}$ pada semua kode semen PCC memenuhi spesifikasi SNI 0302-2014 yang dipersyaratkan. Semakin banyak penambahan fly ash di dalam semen maka semakin tinggi kadar $\mathrm{MgO}$. $\mathrm{MgO}$ terutama diperoleh dari penguraian (dekomposisi) dolomit, $\mathrm{CaCO}_{3}, \mathrm{MgCO}_{3}$ yang terdapat dalam batu kapur dan dapat juga berasal dari mineral-mineral tanah liat. Semen yang mengandung $\mathrm{MgO}$ dengan 
kadar yang terlalu tinggi menyebabkan semen mengalami ekspansi yang dapat merusak konstruksi bangunan dan menyebabkan menurunnya kualitas semen (Lamond \& Pielert, 2006).

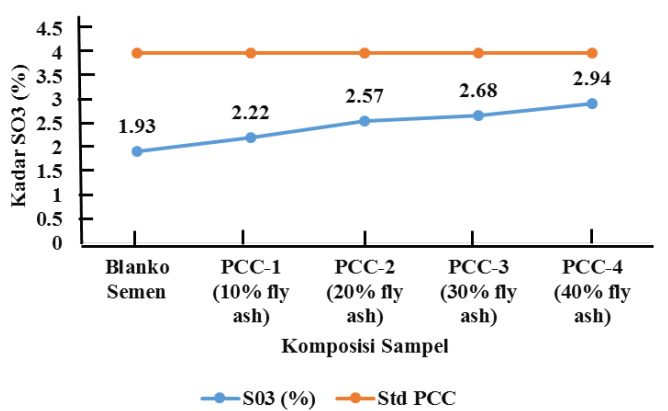

Gambar 9. Komposisi $\mathrm{SO}_{3}$ dalam Semen PCC

\section{f. Hasil komposisi SO3 dalam Semen PCC}

Gambar 9 menunjukkan bahwa kadar $\mathrm{SO}_{3}$ terendah terdapat pada PCC-1 (10\% fly ash) sebesar 2,22\% dan kadar $\mathrm{SO}_{3}$ tertinggi terdapat pada PCC-1 (10\% fly ash) sebesar 2,94 \%. Pada SNI 15-0302-2014 batas maksimum kadar $\mathrm{SO}_{3}$ yang ditetapkan adalah $4,00 \%$. Semua kode semen PCC mengandung kadar $\mathrm{SO}_{3}$ yang memenuhi persyaratan SNI 0302-2014.

\section{Hasil Uji Fisika}

Uji fisika yang meliputi uji kehalusan (blaine), uji kadar air, uji air contain, uji pemuaian (autoclaf), dan uji setting time. Hasil uji fisika dapat dilihat pada Tabel 7.

\section{Pengaruh Komposisi PCC Terhadap Kehalusan Semen dengan Alat Blaine}

Gambar 10 menunjukkan hasil analisis yang telah dilakukan diperoleh bahwa blaine terendah terdapat pada PCC-1 (10\% fly ash) sebesar $396 \mathrm{~m}^{2} / \mathrm{kg}$ dan blaine tertinggi terdapat pada PCC-4 (40\% fly ash) sebesar $472 \mathrm{~m}^{2} / \mathrm{kg}$. Batas minimum kehalusan (blaine) yang ditentukan oleh SNI 03022014 yaitu minimum $280 \mathrm{~m}^{2} / \mathrm{kg}$, jadi kehalusan (blaine) PCC masih memenuhi spesifikasi SNI 15-0302-2014 yang dipersyaratkan.

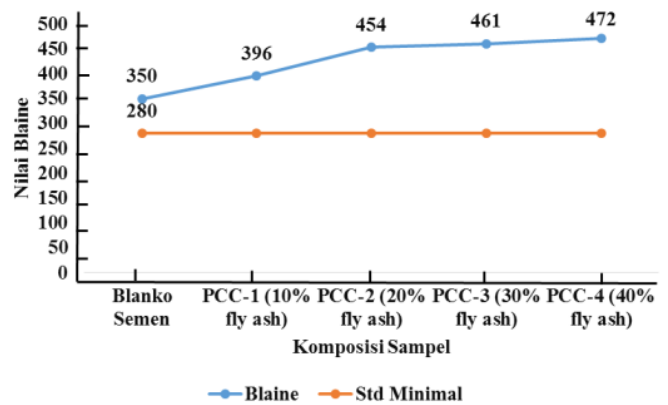

Gambar 10. Pengaruh komposisi Penambahan fly ash pada semen terhadap kehalusan

Uji kehalusan dan uji residu ini dilakukan untuk mengetahui ukuran partikel dari semen, semakin kecil ukuran partikelnya maka residu yang tertinggal di saringan akan semakin sedikit dan menghasilkan nilai kehalusan yang tinggi. Kehalusan (blaine) berbanding terbalik dengan hasil residu. Semakin halus semen maka kadar residu pun semakin kecil, begitupun sebaliknya. Kecepatan reaksi hidrasi semen akan bertambah cepat dengan semakin halusnya ukuran partikel semen, karena semakin halus ukuran partikel semen maka luas permukaannya lebih besar dan reaksi dengan air (hidrasi) semakin cepat.

Tabel 7. Hasil Uji Fisika

Pengujian Fisika

\begin{tabular}{|c|c|c|c|c|c|c|c|c|}
\hline & \multirow{2}{*}{$\begin{array}{l}\text { Blaine }\left(\mathrm{m}^{2}\right. \\
\quad / \mathrm{Kg})\end{array}$} & \multirow{2}{*}{$\begin{array}{c}\text { Residu } \\
45 \mathrm{u} \\
(\%)\end{array}$} & \multirow{2}{*}{$\begin{array}{c}\text { Air } \\
\text { Contain } \\
(\%)\end{array}$} & \multirow{2}{*}{$\begin{array}{c}\text { Pemuaian } \\
\text { Autoclaf } \\
(\%)\end{array}$} & \multicolumn{4}{|c|}{ Setting Time (menit) } \\
\hline & & & & & $\mathrm{NC}$ & Penetrasi & Initial & Final \\
\hline STD & Min. 280 & & maks. 12 & Maks. 0.80 & & & $\begin{array}{c}\text { Min. } 45 \\
\text { menit }\end{array}$ & $\begin{array}{l}\text { maks. } 7 \text { jam } \\
\text { (420 menit) }\end{array}$ \\
\hline Blanko semen & 350 & 8,81 & 7,86 & 0,05 & 23,84 & 10 & 152 & 237 \\
\hline PCC-1 FA $10 \%$ & 396 & 7,94 & 8,92 & 0,06 & 26,77 & 10 & 172 & 277 \\
\hline PCC-2 FA $20 \%$ & 454 & 6,75 & 9,79 & 0,08 & 26,88 & 10 & 177 & 287 \\
\hline PCC-3 FA $30 \%$ & 461 & 5,37 & 11,28 & 0,09 & 26,92 & 9 & 184 & 292 \\
\hline PCC-4 FA $40 \%$ & 472 & 3,86 & 11,63 & 0,12 & 27,12 & 10 & 196 & 298 \\
\hline
\end{tabular}


Semakin halus ukuran partikel semen maka semakin cepat terjadi hidrasi dan semakin cepat juga mengeras (Suprapto, 1995).

\section{Pengaruh Komposisi PCC Terhadap Uji Kandungan Udara / Air Contain}

Semakin banyak penambahan fly ash maka semakin halus semen yang dihasilkan, permukaan pori-pori pada semen semakin banyak sehingga udara yang dapat masuk kedalam pori-pori semakin banyak. Nilai kandungan udara terendah berada pada semen PCC-1 (10\% fly ash) sebesar 8,92\% sedangkan nilai kandungan udara tertinggi berada pada semen PCC-4 (40\% fly ash) sebesar 11,63 \%. Berdasarkan SNI kandungan udara maksimum $12 \%$ itu artinya bahwa pembuatan PCC dari 1-4 memenuhi persyaratan.

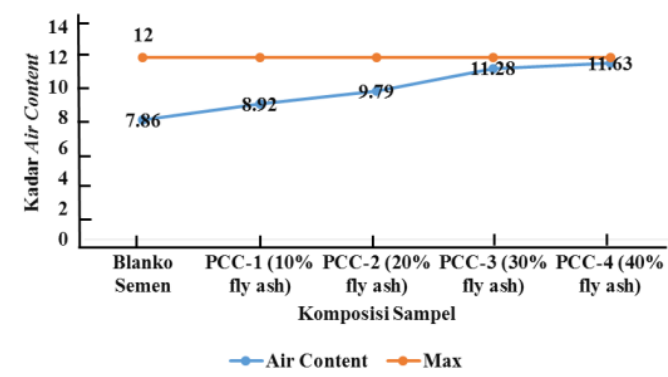

Gambar 12. Pengaruh Komposisi

Penambahan Fly Ash Pada Semen terhadap Kandungan Udara (Air Contain)

\section{Pengaruh komposisi PCC Terhadap Uji Pemuaian Menggunakan Alat Autoclaf}

Uji pemuaian autoclaf bertujuan untuk melihat secara fisik dalam pembuatan semen PCC menggunakan fly ash terjadi pemuaian atau penyusutan dalam pemanasan dengan tekanan tinggi. Dari hasil data yang diperoleh tidak terlalu signifikan perbedaannya, sehingga pemuaian yang terjadi sangat kecil. Pemuaian terendah terjadi pada semen PCC-1 (10\% fly ash) sebesar $0,04 \%$ sedangkan pemuaian paling tinggi terjadi pada semen PCC-4 (40\% fly ash) sebesar 0,10\% dikarenakan pemakaian fly ash yang semakin banyak mengakibatkan adanya penambahan panjang dari pasta semen yang dibuat namun dapat disimpulkan pemuaiannya kecil. Seperti terlihat pada Gambar 13.

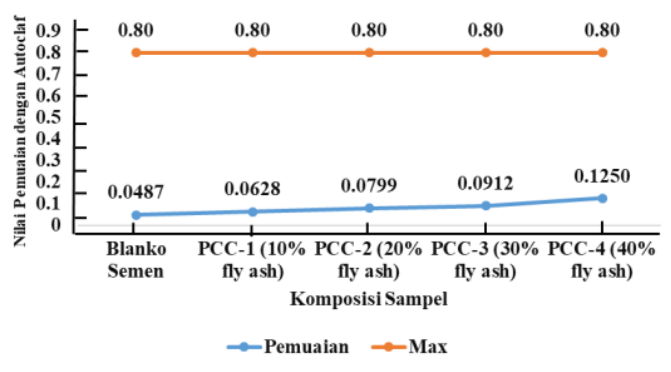

Gambar 13. Pengaruh Komposisi Penambahan Fly Ash Pada Semen Terhadap Kadar Pemuaian

\section{Pengaruh Komposisi PCC Terhadap Uji Normal Consistency}

Gambar 14 menunjukkan bahwa NC terendah terdapat pada PCC-1 (10\% fly ash) sebesar $26,77 \%$ dan $\mathrm{NC}$ tertinggi terdapat pada PCC-4 (40\% fly ash) sebesar 27,12\%. Penentuan Normal Consistency (NC) ini tidak ada batasan khusus yang diatur oleh SNI 0302-2014. Konsistensi normal adalah suatu nilai perbandingan antara massa air yang digunakan dalam massa semen yang dinyatakan dalam persen. Semen sebagai perekat hidrolis memerlukan air untuk proses hidrasi. Banyaknya air untuk proses hidrasi sangat tergantung dari komposisi senyawa dalam semen. Jika air untuk proses hidrasi tersebut kurang, maka tidak semua butiran semen akan terhidrasi, demikian pula jika air terlalu banyak, maka kekuatan pasta (semen campur air) semen akan menurun. Untuk itu perlu diketahui banyaknya air yang diperlukan, maka dilakukan pengujian konsistensi normal (Lamond \& Pielert, 2006).

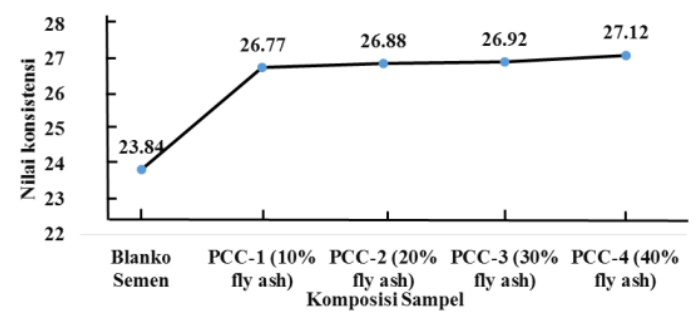

Gambar 14. Pengaruh Komposisi Penambahan Fly Ash Pada Semen Terhadap Uji Normal Consistency 


\section{Pengaruh Komposisi PCC Terhadap Uji Setting Time}

Gambar 15 menunjukkan bahwa initial setting time (waktu ikat awal) terendah terdapat pada PCC-1 (10\% fly ash) selama 172 menit dan initial setting time tertinggi terdapat pada PCC-4 (40\% fly ash) selama 196 menit. Batas minimum initial setting time (waktu ikat awal) yang ditentukan oleh SNI 0302-2014 adalah minimum 45 menit jadi initial setting time PCC ini memenuhi spesifikasi SNI 03022014 yang dipersyaratkan.

Gambar 15 menunjukkan bahwa final setting time (waktu ikat akhir) tercepat terdapat pada PCC-1 (10\% Fly ash) selama 277 menit . Nilai Initial Setting terlama terdapat pada PCC-4 (40\% Fly ash) selama 298 menit. Batas maksimum final setting time (waktu ikat akhir) yang ditentukan oleh SNI 0302-2014 adalah maksimum 7 jam atau 420 menit jadi final setting time PCC ini memenuhi spesifikasi SNI 0302-2014 yang dipersyaratkan. Gambar 15 menunjukkan bahwa penambahan fly ash pada PCC akan berpengaruh pada peningkatan waktu ikat awal dan waktu ikat akhir pada semen.

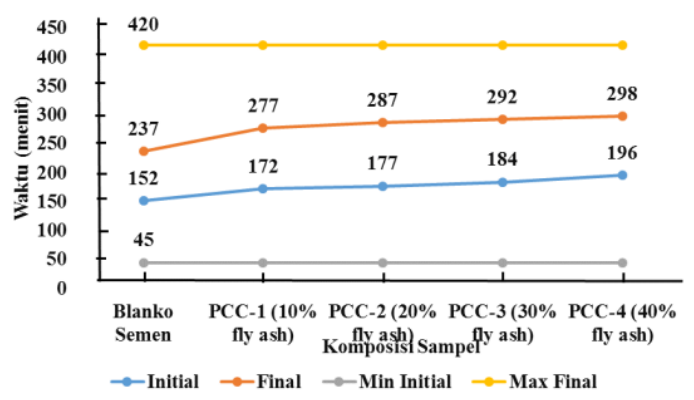

Gambar 15. Pengaruh Komposisi Penambahan Fly Ash Pada Semen Terhadap Setting Time

Proses setting time adalah perubahan pasta semen dalam keadaan plastis menjadi solid, segera setelah setting time dari pasta semen tidak kuat dan kekuatan desaknya menjadi kecil. Dengan berlalunya waktu dan bersamaan dengan proses hidrasi, pasta semen tersebut menjadi keras dan dengan sendirinya kekuatan desaknya menjadi bertambah. Selama proses pengerasan dari pasta ke massa yang keras seperti batu, semen mengalami dua tipe setting time yaitu intial setting time dan final setting time. Intial setting time berlangsung saat semen mulai menjadi kaku setelah semen dicampur dengan air. Setelah intial setting time, pasta semen masih dalam keadaan keras dan makin menjadi kaku dan cukup kuat menahan tekanan.

Pada reaksi semen, $\mathrm{C}_{3} \mathrm{~A}$ akan bereaksi paling cepat menghasilkan CAH (Calsium Aluminate Hydrate) berbentuk gel dan bersifat kaku. Tetapi CAH akan beraksi dengan gipsum membentuk ettringite yang akan membungkus permukaan $\mathrm{CAH}$ dan $\mathrm{C}_{3} \mathrm{~A}$ sehingga reaksi $\mathrm{C}_{3} \mathrm{~A}$ akan dihalangi dengan proses setting akan dicegah. Namun demikian, lapisan ettringite tersebut karena adanya fenomena osmosis akan pecah dan reaksi hidrasi $\mathrm{C}_{3} \mathrm{~A}$ akan terjadi lagi, tetapi segera pula akan terbentuk ettringite yang baru kembali, proses ini akan menghasilkan setting time. Oleh karena itu diperlukan gipsum pada penambahan aditif semen.

Setting time dipengaruhi oleh kandungan $\mathrm{SO}_{3}$ dan kandungan $\mathrm{C}_{3} \mathrm{~A}$ di dalam semen. Pada penelitian ini digunakan gipsum dengan kadar konsentrasi tetap 3\% dari semen sehingga tidak dapat dilihat pengaruhnya. Kadar $\mathrm{C}_{3} \mathrm{~A}$ dalam klinker pun dapat mempengaruhi setting time. Klinker yang ditambahkan dari PPC-1 sampai PPC-8 semakin sedikit, jadi kadar $\mathrm{C}_{3} \mathrm{~A}$ pun semakin sedikit. Semakin banyak kandungan $\mathrm{C}_{3} \mathrm{~A}$ maka setting time cenderung semakin pendek (Roosyanto, 1992).

\section{Pengaruh Komposisi PPC Terhadap Kuat Tekan (Compressive Strength) \\ Kuat tekan merupakan kemampuan} suatu bahan atau struktur dalam menahan beban tekan. Kuat tekan adalah karakteristik yang paling utama untuk semen. Perbedaan kuat tekan semen dipengaruhi oleh komposisi mineral, magnesium, kandungan gipsum, kapur bebas, suhu, rasio air dengan semen, kualitas agregat, perlakuan, dan cara pengerjaan. Kecepatan pengembangan kuat tekan semen dipengaruhi oleh komposisi mineral yang terkandung dalam semen. Mineral utama yang terkandung dalam semen yaitu $\mathrm{C}_{3} \mathrm{~S}, \mathrm{C}_{2} \mathrm{~S}, \mathrm{C}_{3} \mathrm{~A}$ dan $\mathrm{C}_{4} \mathrm{AF}$ yang memiliki reaktifitas berbeda-beda ketika bereaksi dengan air (Suprapto, 1995). Berikut hasil pengujian 
kuat tekan semen PCC ditampilkan dalam Tabel 8.

Gambar 16 menunjukkan bahwa kuat tekan terendah umur 7 hari terdapat pada PCC-4 (40\% fly ash) sebesar $245 \mathrm{~m}^{2} / \mathrm{Kg}$ dan kuat tekan tertinggi umur 7 hari terdapat pada PCC-1 (10\% fly ash) sebesar 316 $\mathrm{m}^{2} / \mathrm{Kg}$. Batas minimum kuat tekan umur 7 hari yang ditentukan oleh SNI 0302-2014 adalah minimum $200 \mathrm{~kg} / \mathrm{cm}^{2}$ jadi kuat tekan PCC ini memenuhi spesifikasi SNI 03022014 yang dipersyaratkan.

Kuat tekan terendah umur 28 hari terdapat pada PCC-4 (40\% Fly ash) sebesar $330 \mathrm{~kg} / \mathrm{cm}^{2}$ dan kuat tekan tertinggi umur 28 hari terdapat pada PCC-1 (10\% Fly ash) sebesar $401 \mathrm{~kg} / \mathrm{cm}^{2}$. Batas minimum kuat tekan umur 28 hari yang ditentukan oleh SNI 0302-2014 adalah minimum $280 \mathrm{~kg} / \mathrm{cm}^{2}$ jadi kuat tekan PCC ini memenuhi spesifikasi SNI 0302-2014 yang dipersyaratkan. Kenaikkan kuat tekan semen pada penambahan fly ash terjadi karena secara kimiawi fly ash bersifat hidrolis yang bereaksi mengikat kapur bebas atau $\mathrm{Ca}(\mathrm{OH})_{2}$ yang dilepaskan semen saat proses hidrasi. Reaksi kimia yang terjadi tersebut membuat kapur bebas yang semula adalah mortar udara mengeras bersama air dan fly ashy ang akhirnya mempengaruhi kekuatan tekan semen. Kadar $\mathrm{Ca}(\mathrm{OH})_{2}$ akibat proses hidrasi yang berkurang karena adanya pengikatan yang terjadi dengan fly ash menyebabkan porositas dan permeabilitas berkurang sehingga membuat mortar lebih padat dan lebih kuat. Fly ash yang butirannya lebih halus dari semen dalam mortar secara mekanik juga akan mempengaruhi kuat tekan mortar sehingga menambah kekedapan dan memudahkan pengerjaan.
Penambahan fly ash ke dalam semen berpengaruh terhadap kuat tekan semen. Semakin besar persentase fly ash yang ditambahkan maka semakin rendah kuat tekan semen tersebut. Semakin banyak fly ash yang ditambahkan, maka klinker yang digunakan menjadi semakin berkurang. Salah satu faktor yang meningkatkan kuat tekan pada semen yaitu senyawa-senyawa yang terkandung di dalam klinker seperti $\mathrm{C}_{2} \mathrm{~S}, \mathrm{C}_{3} \mathrm{~S}, \mathrm{C}_{3} \mathrm{~A}$, dan $\mathrm{C}_{4} \mathrm{AF}$.

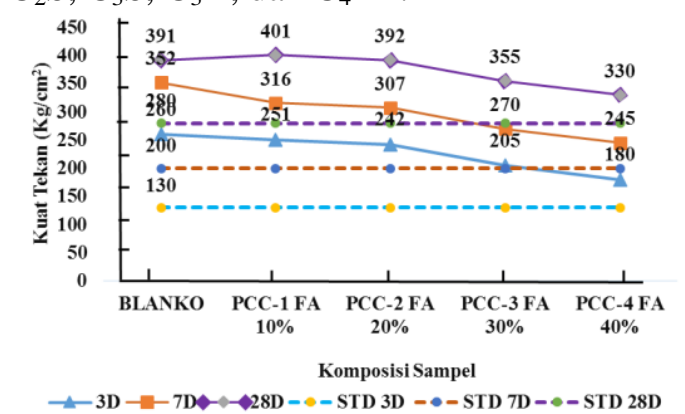

Gambar 16. Komposisi Fly Ash terhadap Kuat Tekan Semen

\section{KESIMPULAN}

Berdasarkan hasil penelitian ini diperoleh optimasi waktu penghalusan limbah fly ash yaitu selama 15 detik dengan pengujian blaine sebesar $878 \mathrm{~cm}^{2} / \mathrm{g}$ dengan nilai residu fly ash sebesar $26,2 \%$. Waktu grinding pada 15 detik paling optimum dan terhomogenisasi dengan cepat. Uji kimia meliputi uji kapur bebas, uji bagian tak larut, uji hilar pijar dan uji dengan XRF (X-Ray Flourescence), sedangkan uji fisika meliputi uji kehalusan, uji residu, uji kandungan air, uji pemuaian, uji setting time, dan uji kuat tekan. Dalam penelitian ini, hasil yang diperoleh dari uji kimia dan fisika dengan penambahan sampel fly ash 10\% - 30\% masih memenuhi persyaratan SNI 0302-201.

Tabel 8. Hasil pengujian kuat tekan semen PCC

\begin{tabular}{|c|c|c|c|}
\hline \multirow{2}{*}{ Kode Semen } & \multicolumn{3}{|c|}{ Kuat Tekan } \\
\hline & 3 Hari $\left(\mathrm{m}^{2} / \mathrm{Kg}\right)$ & 7 Hari $\left(\mathrm{m}^{2} / \mathrm{Kg}\right)$ & 28 Hari $\left(\mathrm{m}^{2} / \mathrm{Kg}\right)$ \\
\hline STD & $\min 130$ & $\min 200$ & $\min 280$ \\
\hline Blanko & 260 & 352 & 391 \\
\hline PCC-1 FA $10 \%$ & 251 & 316 & 401 \\
\hline PCC-2 FA $20 \%$ & 242 & 307 & 392 \\
\hline PCC-3 FA $30 \%$ & 205 & 270 & 355 \\
\hline PCC-4 FA $40 \%$ & 180 & 245 & 330 \\
\hline
\end{tabular}




\section{DAFTAR PUSTAKA}

American Society for Testing and Material. (2016). ASTM C109 Test Method for Compressive Strength of Hydraulic Cement Mortars. Annual Book of ASTM Standard Section 4. United States of America: ASTM International.

American Society for Testing and Material. (2016). ASTM C204-96 Test Methode for Fineness of Hydraulic Cement by Air Permeability Apparatus. Annual Book of ASTM Standard Section 4. United States of America: ASTM International.

American Society for Testing and Material. (2016). ASTM C430 Standard Test Method for Fineness of Hydraulic Cement by The $45 \mu \mathrm{m}$ (no 325) sieve. Annual Book of ASTM Standard Section 4. United States of America: ASTM International.

American Society for Testing and Material. (2016). ASTM C114 Standard Test Method for Chemical Analysis. Annual Book of ASTM Standard Section 4. United States of America: ASTM International.

American Society for Testing and Material. (2016). ASTM C187 Standard Test Method for Normal Consistency. Annual Book of ASTM Standard Section 4. United States of America: ASTM International.

Lamond, J. F., \& Pielert, J. H. (2006). Significance of Tests and Properties of Concrete and Concrete-Making Materials. United States of America: ASTM International.

Lea, F. M., \& Desch, C. H. (1976). The Chemistry of Cement and concrete.Third Edition. London: Edward Arnold Ltd.

Lutfy, A. B., Genta, A., Rachmimoellah, \& Romanus, K. T. N. (2013).
Pengeringan Low Rank Coal dengan Menggunakan Metode Pemanasan tanpa Kehadiran Oksigen (bachelor's thesis). Institut Teknologi Sepuluh November, Surabaya, Indonesia.

Maryoto, A. (2008). Pengaruh Penggunaan High Volume Fly Ash Pada Kuat Tekan Mortar (bachelor's thesis). Universitas Jendral Soedirman, Purwokerto, Indonesia.

Rendy. (2014). Analisis Batubara dalam Penentuan Kualitas Batubara untuk Pembakaran bahan baku semen. PT. Indocement Tunggal Prakarsa, Tbk, Bandung.

Roosyanto, S. (1992). Instrumentasi. Industrial Relation Divison Training and Development Dept. PT. Indocement Tunggal Prakarsa, Tbk, Bogor.

Standar Nasional Indonesia. (2014). SNI 150302-2004 Semen Portland Pozzolan. Jakarta: Badan Standarisasi Nasional.

Standar Nasional Indonesia. (2014). SNI $15-$ 2049-2004 Semen Portland. Jakarta: Badan Standarisasi Nasional.

Suprapto, B. B. (1995). Teknologi Semen. Industrial Relation Divison Training and Development Dept. PT. Indocement Tunggal Prakarsa, Tbk, Bogor.

Vera, Roosyanto, \& Erry. 2000. Semen Portland Bahan Baku Sifat-Sifat dan Pengujian. Industrial Relation Divison Training and Development Dept. PT. Indocement Tunggal Prakarsa, Tbk, Bogor. 